\title{
IMPLEMENTASI ROLEPLAY DALAM PEMBELAJARAN BAHASA JEPANG OLEH GURU DI SMK NEGERI 1 SINGARAJA
}

\author{
Ningsih, J.KD.NI ${ }^{1}$, I. W. Sadyana ${ }^{2}$, dan G.S. Hermawan ${ }^{3}$ \\ ${ }^{123}$ Jurusan Pendidikan Bahasa Jepang, Universitas Pendidikan Ganesha, Singaraja,Bali \\ e-mail: juni.ningsih@yahoo.com \\ wayan.sadyana@undiksha.ac.id satya.hermawan@undiksha.ac.id
}

\begin{abstract}
Abstrak
Penelitian ini bertujuan untuk (1) mendeskripsikan implementasi roleplay dalam pembelajaran bahasa jepang di SMK Negeri 1 Singaraja dan (2) kendala yang dialami guru dalam pembelajaran bahasa Jepang dalam implementasi metode roleplay di SMK Negeri 1 Singaraja. Penelitian ini adalah metode penelitian deskriptif kualitatif. Subjek penelitian ini adalah guru bahasa jepang SMK Negeri 1 Singaraja. Teknik pengumpulan data dilaksanakan melalui observasi, wawancara, dan dokumentasi. Teknik analisis data pada penelitian ini dilakukan melalui reduksi data, penyajian data, dan penarikan kesimpulan. Berdasarkan analisis yang dilakukan, diperoleh hasil sebagai berikut. (1) Implementasi roleplay dalam pembelajaran bahasa jepang di SMK Negeri 1 Singaraja dilaksanakan melalui kegiatan ouyou renshuu meningkatkan keterampilan berbicara (2) Kendala yang dialami dalam penerapan roleplay, yaitu keterbatasan waktu dalam proses pembelajaran, kurangnya pengetahuan siswa mengenai hatsuon (pengucapan) dalam pengucapan bahasa Jepang, dan kecenderungan siswa menghafal tanpa mengetahui makna percakapan sehingga terkesan kurang menghayati.
\end{abstract}

Kata-kata kunci: metode roleplay, keterampilan berbicara.

\section{要旨}

本論の目的は（1）シンガラジャ第 1 専門高等学校の日本語科授業における使用されるロールプ レイ、（2）ロールプレイ学習法による日本語科授業において同校指導者が直面する問題を

明らかにすることである。本論は定性的記述研究である。調査対象は、シンガラジャ第 1 専門高 等学校の日本語同校指導者である。データは授業観察、インタビュー、ドクメンテーションであ る。本論の分析法としてはデータ整理、データの提示

, 結論でである。この調査の結果は（1）シンガラジャ第1専門高等学校の日本語科授業におい て、会話力を向上するため実施されるロールプレイ学習に応用練習を使用されている。（2 ）ロールプレイ学習法において直面する問題点としては、授業時間、発音、覚え方である。

キーワード：ロールプレイ学習法、日本語、会話力

\section{Pendahuluan}

Bahasa Jepang merupakan salah satu bahasa asing yang dipelajari di Indonesia dan masuk ke dalam kurikulum pendidikan khususnya pada tingkat sekolah menengah atas dan kejuruan. Proses pembelajaran bahasa Jepang pada tingkat sekolah didasarkan pada kurikulum yang berlaku di sekolah tersebut. Pada umumnya capaian dari pembelajaran ini, yaitu peserta didik mampu berkomunikasi menggunakan bahasa Jepang seperti bekerja dihotel, menjadi guru ataupun instruktur bahasa Jepang, bahkan menjadi tenaga kerja di Jepang. Hal inilah yang menunjukkan pentingnya keterampilan bahasa Jepang mengingat peluang kerja kedepannya yang cukup menjanjikan.

Proses pembelajaran bahasa, khususnya dalam bahasa Jepang memiliki empat aspek keterampilan yang harus dikuasai, yaitu keterampilan menyimak membaca, menulis, dan berbicara. Berdasarkan keempat aspek keterampilan tersebut, berbicara merupakan keterampilan yang diprioritasikan dalam proses pembelajaran sehingga peserta didik harus menguasai keterampilan ini terlebih dahulu sebelum mempelajari eterampilan berbahasa 
lainnya. Berbicara merupakan alat komunikasi yang digunakan untuk menyampaikan ide dan topik kepada lawan bicara. Agar ide dan topik tersebut dapat tersampaikan dengan baik, maka dalam berbicara menggunakan bahasa Jepang harus memperhatikan ketepatan penggunaan kosakata dan pola kalimat.

Meskipun keterampilan berbicara sangat diprioritaskan dalam proses pembelajaran, nyatanya keterampilan ini menjadi kelemahan yang mendasar dalam pembelajaran bahasa Jepang. Hal ini terjadi, diakibatkan oleh penerapan metode pembelajaran yang digunakan oleh guru dalam membentuk keterampilan berbicara. Berdasarkan pengamatan awal di SMK Negeri 1 Singaraja, selama ini guru lebih cenderung menggunakan metode pembelajaran konvensional yang monoton dan kurang menarik sehingga kelas menjadi pasif serta banyak siswa beranggapan bahwa mata pelajaran Bahasa Jepang merupakan mata pelajaran yang membosankan dan membingungkan.

Berdasarkan hal tersebut, tentunya diperlukan suatu upaya peningkatan kualitas pembelajaran bahasa Jepang melalui penerapan metode pembelajaran yang memfasilitasi aktivitas belajar siswa, atau yang berpusat pada siswa (student centered). Metode pembelajaran ini adalah metode yang berpaham konstruktivisme salah satunya adalah metode pembelajaran roleplay. Metode pembelajaran roleplay adalah metode pembelajaran yang melibatkan interaksi antara dua siswa atau lebih tentang suatu topik atau situasi (Yamin, 2005: 76). Metode pembelajaran roleplay juga merupakan metode pembelajaran yang sangat tepat dalam mengembangkan keterampilan berbicara melalui interaksi yang optimal antar peserta didik.

Joyce, et al (2009: 341) memaparkan manfaat roleplay dalam pembelajaran, yaitu (i) siswa dapat meningkatkan kemampuan dalam mengenali dan memperhitungkan perasaannya sendiri serta perasaan orang lain. Ini berarti siswa dapat memiliki perilaku baru dalam menghadapi situasi sulit yang tengah dihadapi dan siswa dapat meningkatkan skill memecahkan masalah. (ii) Role playing mampu merangsang timbulnya beberapa aktivitas. Ini berarti siswa dapat mengekspos nilai-nilai, perasaan, solusi masalah, dan tingkah laku yang ada dan terpendam dalam diri siswa.

Melalui metode pembelajaran roleplay akan dapat menambah pengalaman belajar siswa dalam hal keterampilan berbicara. Hal ini dikarenakan melalui metode pembelajaran roleplay yang berbasis performance akan dapat membangun aspek psikomotor siswa sehingga memberikan kontribusi dalam pencapaian hasil belajarnya. Inilah yang menjadi dasar penelitian ini dilakukan untuk mengkaji implementasi metode pembelajaran roleplay dalam pembelajaran Bahasa Jepang di SMK N 1 Singaraja. Dasar penentuan SMK Negeri 1 Singaraja sebagai acuan peneliti dalam menentukan lokasi penelitian adalah profil lulusan yang mengamanatkan peluang kerja pada sektor pariwisata khususnya kelas APH. Sektor ini tidak terlepas dari keterampilan berbicara salah satunya keterampilan berbicara Bahasa Jepang.

Berdasarkan uraian di atas, metode roleplay yang mampu memberikan pengalaman nyata kepada siswa untuk menggunakan dan menerapkan konsep-konsep kebahasaan sangat menarik untuk dideskripsikan. Hal ini dikarenakan, roleplay memberi motivasi kepada siswa untuk mengembangkan dan melengkapi konsep penggunaan bahasa. Selain itu, metode roleplay juga mampu membuat siswa percaya diri dalam mempelajari pembelajaran bahasa, terutama bahasa Jepang. Dasar inilah yang diajukannya penelitian dengan judul " Implementasi Roleplay dalam Pembelajaran Bahasa Jepang oleh Guru di SMK Negeri 1 Singaraja". Dalam penelitian ini peneliti akan meneliti dua hal yaitu, 1) Bagaimana implementasi roleplay dalam pembelajaran bahasa Jepang di SMK Negeri 1 Singaraja? 2) bagaimana kendala pembelajaran bahasa Jepang dengan metode roleplay oleh guru bahasa Jepang di SMK Negeri 1 Singaraja?

\section{Metode}

Metode penelitian pada prinsipnya adalah prosedur atau cara yang ditempuh dalam penelitian. Metode penelitian meliputi (1) pendekatan dan jenis penelitian, (2) lokasi penelitian (3) subyek dan obyek penelitian, (4) sumber data (5) metode pengumpulan data (6) metode dan teknik analisa. Pendekatan penelitian dalam penelitian ini menggunakan 
pendekatan penelitian kualitataif. Lokasi penelitian dilakukan di SMK Negeri 1 Singaraja. Subjek dalam penelitian ini adalah guru SMK Negeri 1 Singaraja. Objek dari penelitian ini adalah implementasi roleplay dalam pembelajaran bahasa jepang oleh guru. Sumber data dalam penelitian ini berupa kata-kata dan tindakan yang akan diperoleh melalui kegiatan wawancara dan observasi berkaitan dengan roleplay dalam pembelajaran bahasa Jepang oleh guru di SMK Negeri 1 Singaraja. Selain itu, sumber data lainnya berupa foto diperoleh melalui kegiatan dokumentasi. Hal ini sesuai dengan pendapat yang disampaikan ole lofland dan Lofland (dalam Moleong, 2006:157) yang menyatakan bahwa "sumber data utama dari penelitian kualitatif adalah berupa kata-kata dan tindakan, selebihnya merupakan data tambahan".

Metode pengumpulan data dari penelitian ini adalah observasi dan wawancara (pengamantan lapangan) dan dokumentasi. Instrumen yang digunakan dalam penelitian ini adalah pedoman wawancara, lembar observasi, dan alat perekam atau video kamera. Analisis data dilakukan dengan metode deskritif kualitatif. Metode dan teknik analisa data dari penelitian ini dilakukan setelah pengumpulan data sesuai dengan tujuan yang inginkan. Reduksi data dalam penelitian ini adalah untuk mendapatkan data yang terkait dengan implementasi roleplay, model roleplay, dan kendala pembelajaran yang dialami dengan metode roleplay.

Penyajian data, Setelah data direduksi, maka langkah selanjutnya adalah penyajian data. Agar lebih sistematis penyajian data dilakukan untuk data yang telah direduksi sehingga terlihat sosok data yang lebih utuh. Dalam penyajian data, laporan yang sudah direduksi dilihat kembali gambarannya secara keseluruhan, sehingga dapat tergambar konteks data secara keseluruhan dan dari situ dapat dilakukan penggalian data kembali apabila dipandang perlu untuk lebih mendalami masalahnya. Kemudian penarikan kesimpulan/verifikasi Kesimpulan awal yang dikemukakan masih bersifat sementara, dan akan berubah bila tidak ditemukan bukti-bukti yang kuat yang mendukung pada tahap pengumpulan data berikutnya.

\section{Hasil dan Pembahasan}

Berdasarkan deskripsi hasil observasi tersebut, dapat disimpulkan bahwa dalam mengajar bahasa Jepang guru menerapkan metode roleplay. Kegiatan proses belajar mengajar dengan metode roleplay dapat dilihat dari kegiatan pada saat guru memberikan latihan-latihan yang dalam bahasa jepang disebut dengan ouyou renshuu. Ouyou renshuu dilakukan dengan tujuan agar pembelajar dapat menggunakan kosakata, pola kalimat dan percakapan yang diajarkan pada tahap latihan dasar. Pada kegiatan ini, terbukti bahwa metode roleplay dapat memantapkan siswa dalam menggunakan kosakata, pola kalimat dan percakapan guru menerapkan metode roleplay. Hal ini terlihat dari antusias siswa dalam bermain peran.

Saat memulai kegiatan roleplay, guru sudah menerapkan hampir semua teknik roleplay seperti, pemberian peran dan mengevaluasi kegiatan. Jadi, pada proses pembelajaran, guru tidak melakukan kegiatan roleplay secara murni melainkan melakukan roleplay modifikasi dengan memberikan contoh percakapan kepada siswa sebelum proses roleplay berlangsung. Sehingga siswa dengan mudah melakukan kegiatan roleplay.

Pada proses pembelajaran tentunya tidak terlepas dari interaksi antara siswa dan guru. Agar terciptanya proses belajar mengajar yang efektif tentunya dibutuhkan kemampuan dari seorang guru sebagai pengajar. Kemampuan guru dalam menguasai materi pelajaran memang penting tetapi itu saja tidak cukup sebagai upaya untuk menciptakan proses belajar mengajar yang efektif. Oleh karena itu, diperlukan penerapan strategi atau metode yang baik dan tepat sehingga guru mampu mengatasi permasalahan yang muncul saat proses pembelajaran di dalam kelas. Metode yang mampu mengatasi permasalahan tersebut adalah metode roleplay. Metode roleplay mampu menciptakan proses belajar mengajar yang efektif dan tidak membosankan. Untuk lebih jelasnya dipaparkan sebagai berikut.

a. Implementasi Roleplay dalam Pembelajaran Bahasa Jepang oleh Guru

1) Roleplay sebagai ouyou renshuu 
Berdasarkan hasil observasi dan wawancara roleplay dilakukan pada saat ouyou renshuu. Matsumoto (2007:13) ouyou renshuu atau latihan penerapan adalah berlatih untuk mengaplikasikannya dalam komunikasi sebenarnya. Ouyou renshuu dilakukan dengan tujuan agar pembelajar dapat menggunakan kosakata dan pola kalimat atau percakapan yang sudah diajarkan sebelumnya. Untuk itu pengajar harus selalu berupaya memikirkan bagaimana cara latihan yang dianggap tepat untuk tahap latihan penerapan tersebut. Berdasarkan hasil observasi pada saat ouyou renshuu guru menerapkan metode roleplay dengan tujuan mengembangkan minat belajar siswa dan agar siswa lebih menarik saat mengikuti pelajaran. Penerapan roleplay yang dilakukan guru telah sesuai dengan langkahlangkah metode roleplay.

Oyou renshuu sebagai kegiatan akhir pembelajaran untuk melatih menggunakan konsepkonsep bahasa. Sebenarnya bisa dilakukan dengan banyak hal antara lain teknik-teknik information gap, pidato, menulis karangan atau membaca bacaan berbahasa jepang. Akan tetapi guru dalam pembelajaran ini menggunakan teknik roleplay, karena kelas ini merupakan kelas pariwisata yang dituntut untuk memiliki kemampuan berbicara. Melalui roleplay, siswa diciptakan situasi dan kondisi tertentu serta diberikan peran-peran tertentu untuk melatih mereka menggunakan bahasa dalam situasi yang nyata dikemudian hari. Jadi, roleplay yang digunakan oleh guru sejalan dengan konsep komunikatif dalam langkah ouyou renshuu karena di dalamnya terdapat roleplay (bermain peran). Selain itu, pada langkah tersebut juga terkandung aspek-aspek ningen kankei (hubungan antar manusia), jouhosha (penerima kosensi), dan bamen (kondisi terntentu). Pada kegiatan latihan seperti ini, siswa diberikan dan diciptakan kondisi real yang seolah-olah nyata seperti keadaan yang sebenarbenarnya. Hal ini akan mempersiapkan siswa untuk menghadapi situasi sebenarnya terkait dengan konsep penggunaan bahasa.

2. Langkah-langkah roleplay

Berdasarkan hasil observasi yang telah dilakukan, guru hampir semua menerapkan langkahlangkah roleplay, adapun langkah-langkah roleplay menurut Hamalik (2011:215) yaitu.

a. Persiapan dan Instruksi

Berdasarkan hasil observasi dan wawancara guru sudah menerapkan persiapan dan instruksi dari langkah-langkah metode roleplay, saat melakukan latihan roleplay guru mempersiapkan bermain peran dengan menentukan topik yang akan dimainkan.

b. Tindakan Dramatik dan Diskusi

Berdasarkan observasi tindakan dramatik dan diskusi sudah diterapkan oleh guru dalam langkah-langkah metode roleplay. Setelah guru memberikan intruksi dan persiapan guru melanjutkan dengan melakukan kegiatan roleplay. Pada saat melakukan kegiatan roleplay siswa yang tidak bermain peran menjadi pengamat. Setelah bermain peran selesai, pemain dan pengamat beserta guru berdiskusi tentang kegiatan yang tadi berlangsung.

c. Evaluasi Bermain Peran

Setelah proses roleplay berlangsung guru mengevaluasi kegiatan tersebut dengan melakukan penilaian. Penilaian ini digunakan guru untuk melengkapi. Berdasarkan hasil wawancara dengan guru, pada proses penilaian guru melakukan penilaian dengan menilai pengucapan (hatsuon), kelancaran siswa saat berbicara, pengucapan kata atau kosakata yang tepat. Pada proses penilaian dilakukan secara langsung oleh guru.

2. Kendala Pembelajaran Bahasa Jepang dengan Metode Roleplay oleh Guru

Pembelajaran bahasa jepang yang sudah terjadwal dengan alokasi waktu tertentu dirasa masih sangat singkat. Hal ini menyebabkan sebagian siswa belum sempat untuk menunjukkan dialognya di depan kelas, sehingga ada siswa yang kelihatannya kecewa karena sudah menghafal dan membuat percakapan namun tidak dapat melakukan kegiatan ini.

Kurangnya pengetahuan siswa mengenai hatsuon (pengucapan) dan intonasi dalam pengucapan bahasa Jepang yang menyebabkan pengucapan siswa banyak yang salah. Seringkali siswa tidak jelas menyampaikan informasi yang berupa pernyataan ataupun pertanyaan. Melihat hal ini, guru melatih kembali agar intonasi yang diucapkan siswa benar. 


\section{Simpulan dan Saran}

Berdasarkan hasil penelitian dan pembahasan yang telah dilakukan dapat disimpulkan sebagai berikut.

1. Implementasi roleplay dalam pembelajaran bahasa jepang di SMK Negeri 1 Singaraja dilaksanakan melalui kegiatan ouyou renshuu meningkatkan keterampilan berbicara. Hal ini dikarenakan roleplay yang digunakan oleh guru sejalan dengan konsep komunikatif dalam langkah ouyou renshuu.

2. Kendala pembelajaran bahasa jepang dengan metode roleplay oleh guru bahasa jepang di SMK Negeri 1 Singaraja, yaitu keterbatasan waktu dalam proses pembelajaran, kurangnya pengetahuan siswa mengenai hatsuon (pengucapan) dalam pengucapan bahasa Jepang, kecenderungan siswa menghafal tanpa mengetahui makna percakapan sehingga terkesan kurang menghayati dan keterbatasan bahan ajar, konfigurasi kemampuan siswa, pengelolaan kelas dalam roleplay, dan proses pembentukan serta kerjasama siswa dalam kelompok.

\section{Daftar Pustaka}

Hamalik, Oemar 2004. Proses Belajar Mengajar. Jakarta : Bumi Aksara.

Joyce, B, et al. 2009. Models of Teaching (Model-Model Pengajaran) edisi ke delapan. Yogyakarta: Pustaka Pelajar.

Khoirunnsia, Selvy Wulan. 2016. Pengaruh Penerapan Model Pembelajaran Roleplaying Terhadap Keterampilan Berbicara Siswa kelas V SD Negeri 1 Pardasuka Katibung Lampung Selatan. Universitas Lampung.

Matsumoto. 2007. Shokyuu o Oshieru. Tokyo : The Japan Foundation

Moleong, L.J. 2000. Metodelogi penelitian kualitatif. Bandung : PT. Remaja Rosda Karya

Munandir. 1990. Riset kualitatif untuk pendidikan: pengantar ke teori dan praktek. Jakarta: Depdikbud

Mustadi, Ali. 2011. speaking skill improvement melalui roleplaying pada kompetensi English for instruction. Universitas Negeri Yogyakarta

Padmadewi, I Nyoman. 2015. Strategi Pembelajaran Bahasa. Singaraja : Undiksha

Priyambodo, B. 2013. Bimbingan melalui Metode Role Play untuk Meningkatkan Prestasi Belajar Bahasa Jepang Siswa SMKN 1 Temanggung. Skripsi. Jurusan Bahasa dan Sastra Asing, Fakultas Bahasa dan Seni, Universitas Negeri Malang. Tersedia pada https://lib.unnes.ac.id/18598/1/2302909013.pdf. Diakses pada tanggal 16 Juli 2019.

Putra, Anggara Wisnu. 2016. Metode Roleplaying untuk Meningkatkan Keterampilan Berbicara Siswa kelas V Sdn Wonosari 4. Skripsi (tidak diterbitkan). Universitas Negeri Yogyakarta.

Restoeningroem. 2014. Teknik Roleplay Terhadap Pembelajaran Berbicara Bahasa Jepang(Kaiwa). Skripsi (tidak diterbitkan). FKIP UHAMKA

Sugiyono.2009. Memahami Penelitian Kualitatif. Bandung : Penerbit Alfabeta

Sugiyono. 2008. Metode penelitian kuantitatif, kualitatif, dan R \& D. Bandung: Alfabeta.

Triono, Edi. 2015. Analisis Pembelajaran Bahasa Jepang di SMA Negeri 1 Bukateja. Skripsi (tidak diterbitkan). Universitas Negeri Malang

Yamin, M. 2005. Desain Pembelajaran Berbasis Tingkat Satuan Pendidikan. Jakarta : Gaung Persada Press. 